\title{
Essential oil composition and anatomical characteristics of Stachys megalodonta Hausskn. \& Bornm. ex P. H. Davis subsp. mardinensis R. Bhattacharjee endemic in Turkey
}

\author{
M. Kurkcuoglu, Sevim Kucuk**, M. Kursat** and K.H.C. Baser*** \\ Department of Pharmacognosy, Faculty of Pharmacy, Anadolu University, Eskisehir-26470, Turkey \\ *Department of Pharmaceutical Botany, Faculty of Pharmacy, Anadolu University, Eskisehir-26470, Turkey \\ **Department of Biology, Faculty of Science and Arts, Bitlis Eren University, Bitlis, Turkey \\ ***Department of Pharmacognosy, Faculty of Pharmacy, Near East University, Near East Boulevard, 99138, Nicosia, N. Cyprus
}

\section{Article Info}

Article history

Received 10 October 2021

Revised 29 November 2021

Accepted 30 November 2021

Published Online 30 December 2021

\section{Keywords}

Stachys megalodonta Hausskn. \&

Bornm. ex P.H. Davis subsp.

mardinensis

Lamiaceae

Essential oil

GC and GC-MS

a-pinene

germacrene D

1,8-cineole

\begin{abstract}
Stachys L. (Deliçay) (Lamiaceae) is presented in Turkey by 89 species. 46 species are endemic in Turkey. Stachys megalodonta Hausskn. \& Bornm. ex P. H. Davis subsp. mardinensis R. Bhattacharjee is locally known as "gevrek deliçay". Stachys spp. are aromatic perennial subshrubs used as spices or herbal teas in the Turkish folk medicine.

The aerial parts of $S$. megalodonta subsp. mardinensis (Lamiaceae) were water distilled for $3 \mathrm{~h}$ using a Clevenger-type apparatus and the oil was analyzed. The essential oil was analyzed by GC-FID and GC/MS, simultaneously. The main constituents were identified as a-pinene (17.7\%), germacrene D (7.2\%), 1,8cineole $(6.1 \%), \beta$-caryophyllene $(4.8 \%)$, limonene $(3.1 \%)$, camphene $(3.1 \%)$ and camphor $(2.9 \%)$. It's morphological, morphometric and anatomical properties are described in the present study. Data obtained after investigations were compared with those in the Davis's "Flora of Turkey". Morphological and anatomical results are supported by photographs and illustrations.
\end{abstract}

\section{Introduction}

Stachys L. is among the largest genera of the Lamiaceae and it contains about 350 species (435 taxa) worldwide. Species of the genus are concentrated in the warm temperate regions of the Mediterranean region and southwestern Asia, with secondary centres in North America, South America, and southern Africa. Native species are absent from Australia and New Zealand. The Asiatic centre contains 2 phytogeographical regions (Mediterranean and Irano-Turanian). The European centre is Mediterranean and EuroSiberian. The first is confined to southern and eastern Anatolia, Caucasia, north-western Iran, and northern Iraq, and the other to the Balkan Peninsula (Bhattacharjee, 1974). Stachys was revised by Bhattacharjee for the Flora of Turkey². Since then, 18 new species have been described from Turkey. Stachys (Deliçay) has 93 species (118 taxa) belonging to 15 sections and 2 subgenera in Turkey. Of the 118 taxa, 57 are endemic in Turkey. Stachys megalodonta has two subspecies: subsp. megalodontha is distributed in Northern Iraq and subsp. mardinensis R. Bhattacharjee. subsp. mardinensis is considered as a taxon in

Corresponding author: Dr. Sevim Kucuk

Professor, Department of Pharmaceutical Botany, Faculty of Pharmacy, Anadolu University, Eskisehir-26470, Turkey

E-mail: salan@anadolu.edu.tr

Tel.: +90-5452997214

Copyright (C) 2021 Ukaaz Publications. All rights reserved.

Email: ukaaz@yahoo.com; Website: www.ukaazpublications.com between S. megalodonta Hausskn. et Bornm \& ex P.H. Davis and S. mardinensis (Post) R.R. Mill. (Baser and Kirimer, 2018; Bhattacharjee, 1974; 1980; 1982; Celep and Dirmenci, 2017; Davis et al., 1988; Duman, 2000; Dinc and Dogu, 2015; Akcicek et al., 2012; Renda et al., 2017; Salmaki et al., 2012). S. megalodonta Hausskn. and Bornm. ex P.H. Davis subsp. mardinensis R. Bhattacharjee is locally known as "gevrek deliçay" (Akcicek, 2012).

Whole plant or leaves are used in phytotherapy due to sedative, antispasmodic, stomachic and diuretic properties in tea preparations (Baytop, 1999; Goger et al., 2016).

S. balansae subsp. balansae, S. mardinensis and S. megalodonta subsp. mardinensis were evaluated. The antimicrobial activity of methanol extracts were determined by minimum inhibitory concentrations (MIC) method, the best activity was observed with $S$. megalodonta subsp. mardinensis against E. coli and S. aureus. In addition, flavonoids content was analyzed by HPLC. The highest phenolic content was found in S. mardinensis and S. megalodonta subsp. mardinensis (79.09 $\mathrm{mg} \mathrm{QE} / \mathrm{g}$ ). According to results, $S$. mardinensis had higher quercetin $(26.5 \mathrm{mg} / \mathrm{g})$ and catechine $(11.00$ $\mathrm{mg} / \mathrm{g}$ ) contents than the other Stachys species (Karaboduk et al., 2014).

To the best of our knowledge, this is the first report on the GC and GC/MS determination of the essential oil composition of Stachys megalodonta subsp. mardinensis. 


\section{Materials and Methods}

\subsection{Plant material}

The flowering aerial parts of Stachys megalodonta subsp. mardinensis was collected from B8: Bitlis: Kambos Mountain on June 26, 2016 (Figures 1-2). Voucher specimens of Stachys megalodonta subsp. mardinensis are deposited in the Herbarium of the Bitlis Eren University (Voucher Specimen code: M.K. 6082) and Herbarium of the Faculty of Pharmacy, Anadolu University in Eskisehir (ESSE: 15295), Turkey. Of the S. megalodonta subsp. mardinensis, botanical identification was carried out by one of us (M. Kursat) (Bhattacharjee, 1980).

\subsection{The isolation of essential oil and GC-GC/MS analysis}

The essential oil obtained from aerial parts of the Stachys megalodonta subsp. mardinensis by analyzed simultaneously using Gas Chromatography (GC) and gas chromatography-mass spectrometry (GC/MS) systems. Volatiles were identified according to their retention indices and mass spectral properties (Kucuk et al., 2019). The results of analysis are shown in Table 1.

\subsection{Anatomical studies}

For anatomical studies, samples have been collected from the irnatural habitats and kept in 70\% alcohol. Root, stem and leaves of mature and flowered plants have been utilized in the study. Investigations were performed on the cross-sections of the root, the flowering stem and the leaf. All sections were embedded in glycerin jelatine and stained by Sartur reactive and photographs were taken through a light microscope (Olympus BX51T).

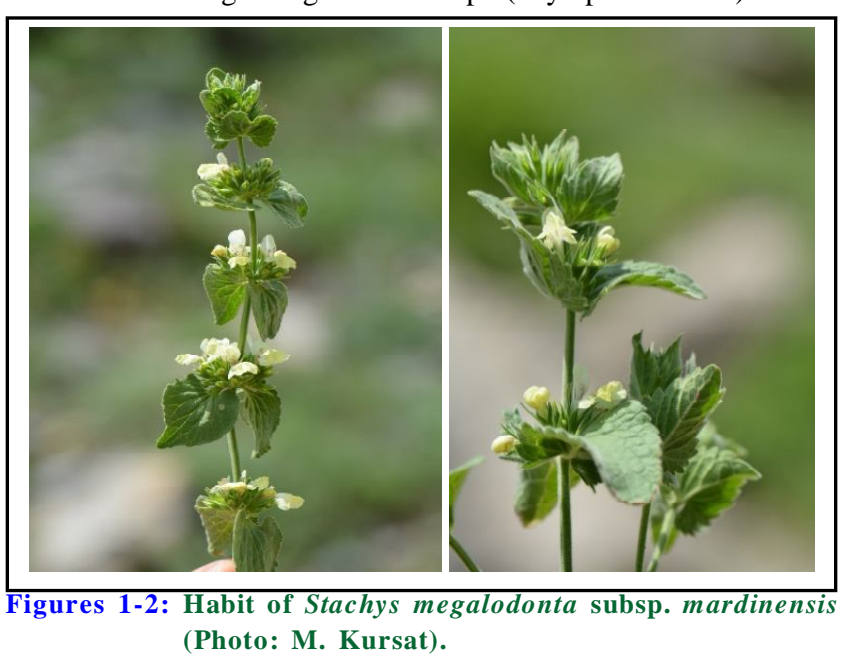

\section{Results and Discussion}

The aerial parts of Stachys megalodonta subsp. mardinensis (Lamiaceae) was water distilled for $3 \mathrm{~h}$ using a Clevenger-type apparatus. The essential oil was analyzed by GC and GC-MS, simultaneously. Eighty-three compounds representing $91.8 \%$ of the essential oil were characterized from $S$. megalodonta subsp. mardinensis. The main constituents were identified as $\alpha$-pinene (17.7\%), germacrene D (7.2\%), 1,8-cineole (6.1\%), $\beta$-caryophyllene $(4.8 \%)$, limonene $(3.1 \%)$, camphene $(3.1 \%)$ and camphor $(2.9 \%)$.

According to previous research report by Kaya and steel, the water distilled essential oil from dried aerial parts of Stachys iberica subsp. stenostachya (Lamiaceae) was analyzed by GC/MS. Seventy-one compounds were characterized representing $96 \%$ of the oil. The main constituents were found as linalyl acetate $(42.2 \%)$, linalool (18.9\%), geranyl acetate (8.2\%), and $\alpha$-terpineol (5.3\%) (Kaya $e t$ al., 2001).

The main constituents for S. laetivirens Kotschy \& Boiss. were found to be nonacosane (23.1\%) and phytol (17.9\%) (Duman et al., 2005).

S. cretica ssp. lesbiaca Rech. f. (germacrene D 20.3, $\beta$-caryophyllene 9.5, $\alpha$-pinene 8.6, $\beta$-pinene 6.2 ) and $S$. cretica ssp. trapezuntica Rech. f. (germacrene D 12.9, octacosane 7.2, linalyl acetate 5.2) were determined by GC and GC-MS (Serbetci et al., 2010).

Chemical compositions of the essential oils of twenty-two Stachys species were evaluated (S.balansae Boiss. and Kotschy subsp. balansae, S. balansae Boiss. \& Kotschy subsp. carduchorum R. Bhattacharjee, S. bayburtensis, R. Bhattacharjee, S. cretica, subsp. anatolica Rech. f., S. cretica subsp. bulgarica Rech. f., S. cretica subsp. cassia (Boiss.) \& Rech.f., S. cretica subsp. garana (Boiss.) Rech. f., S. cretica subsp. kutahyensis Akcicek, S. cretica subsp. lesbiaca (Boiss.) Rech.f., S. cretica subsp. symrnaea (Boiss.) Rech.f., S. germanica subsp. bithynica (Boiss.) R. Bhattacharjee, S. germanica subsp. heldreichii(Boiss.) Hayek, S. huber-morathii R., Bhattacharjee, S. huetii Boiss, S. longispicata Boiss. \& Kotschy, S. obliqua Waldst. \& Kit, S. pinetorum Boiss. \& Bal., S. sericantha P.H. Davis, S. spectabilis, Choisy ex DC, S. thirkei C. Koch, S. tmolea Boiss, S. viticina (Boiss.). Thirty-nine compounds, which accounted for 70.5-97.8\% of the total composition of oils, were reported. Germacrene-D (2.9-45.3\%), $\beta$-caryophyllene (2.3$62.3 \%$ ), caryophyllene oxide (trace to $12.8 \%$ ), spathulenol (trace to $7.8 \%)$ and $\alpha$-cadinene (1.4-8.5\%) were identified as the major components of the essential oil of species. Additionally, $\alpha$-cadinol, $\alpha$-bisabolol, $\alpha$-copaene and bicyclogermacrene were determined (Goren et al., 2011).

The S. lavandulifolia Vahl. subsp. lavandulifolia essential oil obtained by hydrodistillation were analyzed both by GC-FID and GC/MS, simultaneously. Thirty seven compounds representing $98.3 \%$ of the oil were characterized. $\beta$-phellandrene (27\%), $\alpha$-pinene $(18.5 \%)$ and germacrene-D (13\%) were found as major components of the oil (Iscan et al., 2012).

S. macrantha (C. Koch) Stearn, S. sylvatica and S. annua ssp. annua var. апnиa were analyzed by a solid phase microextraction (SPME) method coupled with gas chromatography-flameionization detector (GC-FID) and gas chromatography/masss pectrometry (GCMS). The major volatile constituents of the investigated three Stachys species were; \pm - pinene $(11.2 \%), p$-cymene $(18.2 \%)$ and carvacrol $(28.8 \%)$ in S. macrantha, S. muurolene $(10.2 \%), \pm$ - cedrene $(11.2 \%)$ and limonene $(37.0 \%)$ in S. sylvatica and \pm -pinene $(11,4 \%)$, 2-pinene (23.1\%) and (Z)-2-ocimene(24.8\%) in S. апnи a ssp. annua var. annua (Renda et al., 2017).

Water distilled essential oil of three species of Stachys was analysed by Kaya and steel. The major components found were hexadecanoic acid $(23.7 \%)$, dodecanoic acid $(11.3 \%)$, and caryophyllene oxide $(10.7 \%)$ for $S$. sericantha P.H. Davis (endemic); $\alpha$-pinene (53\%), $\beta$ pinene $(8.2 \%)$ for $S$. gaziantepensis M. Dinc and for S. mardinensis (Post) R. Mill. menthyl acetate $(15.3 \%)$, isomenthone $(15.0 \%)$, pulegone $(10 \%)$, spathulenol $(7.0 \%)$, and caryophyllene oxide (6.7\%) (Kaya et al., 2017). Karaboduk and steel studied antimicrobial and antioxidant activities of $S$. balansae subsp. balansae, S. mardinensis and S. megalodonta subsp. mardinensis were evaluated (Karaboduk et al., 2014). 
Table 1: The Composition of the essential oil of Stachys megalodonta subsp. mardinensis

\begin{tabular}{|c|c|c|c|}
\hline RRI & Compounds & $\%$ & IM \\
\hline 1014 & Tricyclene & 0.8 & MS \\
\hline 1032 & $\alpha$-Pinene & 17.7 & $\mathrm{t}_{\mathrm{R}}, \mathrm{MS}$ \\
\hline 1076 & Camphene & 3.1 & $\mathrm{t}_{\mathrm{R}}, \mathrm{MS}$ \\
\hline 1118 & $\beta$-Pinene & 1.7 & $t_{R}$, MS \\
\hline 1132 & Sabinene & 0.8 & $\mathrm{t}_{\mathrm{R}}, \mathrm{MS}$ \\
\hline 1174 & Myrcene & 0.5 & $t_{R}$, MS \\
\hline 1188 & $\alpha$-Terpinene & 0.1 & $\mathrm{t}_{\mathrm{R}}, \mathrm{MS}$ \\
\hline 1203 & Limonene & 3.1 & $t_{R}$, MS \\
\hline 1213 & 1,8-Cineole & 6.1 & $t_{R}, M S$ \\
\hline 1225 & (Z)-3-Hexenal & 0.3 & $t_{R}$, MS \\
\hline 1255 & $\gamma$-Terpinene & 0.3 & $t_{R}$, MS \\
\hline 1280 & $p$-Cymene & 0.2 & $t_{R}$, MS \\
\hline 1290 & Terpinolene & 0.1 & $t_{R}$, MS \\
\hline 1450 & $\begin{array}{l}\text { trans-Linalool oxide } \\
\text { (Furanoid) }\end{array}$ & $\mathrm{t}$ & MS \\
\hline 1452 & 1-Octen-3-ol & 1.0 & $t_{R}$, MS \\
\hline 1474 & trans-Sabinene hydrate & 0.1 & $t_{\mathrm{R}}, \mathrm{MS}$ \\
\hline 1479 & cis-Linalool oxide (Furanoid) & 0.1 & MS \\
\hline 1484 & Bicycloelemene & 0.6 & MS \\
\hline 1485 & $\alpha$-amorphene & 0.2 & MS \\
\hline 1497 & $\alpha$-Copaene & 2.9 & MS \\
\hline 1529 & $\alpha$-Bourbonene & 0.1 & MS \\
\hline 1532 & Camphor & 2.9 & $t_{R}, M S$ \\
\hline 1535 & $\beta$-Bourbonene & 1.5 & $t_{R}$, MS \\
\hline 1544 & $\alpha$-Gurjunene & 0.1 & MS \\
\hline 1550 & $\beta$-Cubebene & 0.2 & MS \\
\hline 1553 & Linalool & 1.6 & $t_{R}$, MS \\
\hline 1577 & $\beta$-Ylangene & 0.7 & MS \\
\hline 1594 & trans $-\beta$-Bergamotene & 0.2 & MS \\
\hline 1600 & $\beta$-Elemene & 0.9 & MS \\
\hline 1602 & $\beta$-Copaene & 0.8 & MS \\
\hline 1611 & Terpinen-4-ol & 1.2 & $\mathrm{t}_{\mathrm{R}}$, MS \\
\hline 1612 & $\beta$-Caryophyllene & 4.8 & $t_{R}$, MS \\
\hline 1641 & iso-isopulegyl acetate & 0.3 & MS \\
\hline 1661 & Alloaromadendrene & $\mathrm{t}$ & MS \\
\hline 1668 & (Z)- $\beta$-Farnesene & 1.1 & MS \\
\hline 1684 & $\gamma$-Gurjunene & 0.2 & MS \\
\hline 1704 & $\gamma$-Muurolene & 0.2 & MS \\
\hline 1706 & $\alpha$-Terpineol & 0.5 & $t_{R}, M S$ \\
\hline 1719 & Borneol & 0.2 & $t_{R}, M S$ \\
\hline 1726 & Germacrene D & 7.2 & MS \\
\hline 1740 & $\alpha$-Muurolene & 2.1 & MS \\
\hline 1751 & Bicyclogermacrene & 1.1 & MS \\
\hline 1772 & $\delta$-Cadinene & 1.5 & $t_{R}$, MS \\
\hline
\end{tabular}

\begin{tabular}{|c|c|c|c|}
\hline 1776 & $\gamma$-Cadinene & 0.1 & MS \\
\hline 1784 & (E)- $\alpha$-Bisabolene & 0.1 & MS \\
\hline 1786 & ar-Curcumene & 0.1 & MS \\
\hline 1787 & $\begin{array}{l}\text { Aromadendra-1(10), } \\
\text { 4(15)-diene }\end{array}$ & 0.2 & MS \\
\hline 1849 & Cuparene & 0.3 & MS \\
\hline 1882 & $\begin{array}{l}\text { 1-Isobutyl 4-isopropyl-2,2- } \\
\text { dimethyl succinate }\end{array}$ & 0.3 & MS \\
\hline 1900 & Epicubebol & 0.2 & MS \\
\hline 1941 & $\alpha$-Calacorene I & 0.2 & MS \\
\hline 1957 & Cubebol & 0.6 & MS \\
\hline 1958 & ( E)- $\beta$-Ionone & 0.1 & MS \\
\hline 1984 & $\alpha$-Calacorene II & 0.1 & MS \\
\hline 2008 & Caryophyllene oxide & 1.5 & $\mathrm{t}_{\mathrm{R}}$, MS \\
\hline 2037 & Salvial-4(14)-en-1-one & 0.2 & MS \\
\hline 2041 & $(E)$-Nerolidol & 0.7 & $t_{R}$, MS \\
\hline 2057 & Ledol & 0.2 & MS \\
\hline 2069 & Germacrene D-4-ol & 0.3 & MS \\
\hline 2096 & Elemol & 0.2 & MS \\
\hline 2104 & Viridiflorol & 0.4 & MS \\
\hline 2123 & Salviadienol & 0.2 & MS \\
\hline 2130 & 1 - $\alpha$-Himachal-4-en- $1-\beta$-ol & 0.2 & MS \\
\hline 2131 & Hexahydrofarnesyl acetone & 0.2 & $t_{R}$, MS \\
\hline 2144 & Spathulenol & 2.1 & $\mathrm{t}_{\mathrm{R}}, \mathrm{MS}$ \\
\hline 2162 & Muurola-4,10(14) dien-1-ol & 0.4 & MS \\
\hline 2192 & Copaborneol & 0.7 & MS \\
\hline 2193 & Eugenol & $\mathrm{t}$ & $\mathrm{t}_{\mathrm{R}}, \mathrm{MS}$ \\
\hline 2209 & T-Muurolol & 0.3 & MS \\
\hline 2232 & $\alpha$-Bisabolol & 1.4 & MS \\
\hline 2243 & Torilenol & 0.3 & MS \\
\hline 2255 & $\alpha$-Cadinol & 0.1 & $\mathrm{t}_{\mathrm{R}}$, MS \\
\hline 2287 & $\begin{array}{l}\text { 8,13-Epoxy-15,16-dino } \\
\text { r-labd-12-ene }\end{array}$ & 0.5 & MS \\
\hline 2312 & 9-Geranyl-p-cymene & 1.3 & MS \\
\hline 2316 & Caryophylladienol I & 0.1 & MS \\
\hline 2333 & Isobicyclogermacrenal & 0.7 & MS \\
\hline 2353 & Caryophyllenol I & 0.1 & MS \\
\hline 2369 & Eudesma-4(15), 7-dien-1 $\beta$-ol & $\mathrm{t}$ & MS \\
\hline 2376 & Manoyl oxide & 1.3 & MS \\
\hline 2396 & epi-Manoyl oxide & 5.9 & MS \\
\hline 2622 & Phytol & 0.1 & MS \\
\hline 2676 & Manool & 0.4 & MS \\
\hline 2736 & Labda-7,14-dien-13-ol & 0.6 & MS \\
\hline
\end{tabular}

RRI: Relative retention indices calculated against n-alkanes. \%: calculated from the FID chromatograms. t: Trace $(<0.1 \%)$. Identification method (IM): $\mathrm{t}_{\mathrm{R}}$, identification based on the retention times $\left(t_{R}\right)$ of genuine compounds on the HP innowax column; MS, identified on the basis of computer matching of the mass spectra with those of the Wiley and Mass Finder libraries and comparison with literature data. 


\subsection{Anatomical results}

The sections taken from root, stem and leaves of Stachys megalodonta subsp. mardinensis were examined and the anatomic features belonging to plants were determined, compared and showed in Figures 3-13.

\subsection{Root}

Root is formed by periderm on the outside and phelloderm where 4-5 radial rows are broken down and phelloderm with 2-3 row tissues. Outer phelloderm cells are broken up or tissue residues belonging to primer cortex is, time to time, crushed are found. Secondary phloem formed of elliptical-shapeless, round shaped, irregular arranged and 4-6 row cells under the periderm is taken part. Cambium is uncertain. Seconder xylem part cover a large area and consist of tracheal elements with big and small sizes in a sclerenchymatic tissue. Pith branches are 2-3 row cells (Figures 3, 4).

\subsubsection{Herbaceous stem}

In cross sections, the stem is rectangular. Covering hairs: multicellular, glandular hairs are four types; head 1 stalk 2 celled, head 1 stalk 1 celled, head 2 stalk 1 celled and head 8 celled (Labiatae type 3-4 rows collenchyma tissue was found in the four angles. Cortex is parenchymatous to endodermis. Endodermis consists of flattened cells can hardly be distinguished from the cortex parenchyma. Pericycle is composed of cylindiric scleranchyma with a lot of layer medullary rays: 1-2 cells wide. Pith branches are in the form of large polygon or round shaped and parenchymatic cells where its walls are lignified. Druse crystals are clearly found in these cells. Phloem forms a narrow ring. Cambium is indistinct, Branches in both types of seconder xylem are especially getting narrow towards the primery xylem. Medullary rays: 1-2 cells wide. Sclerenchymatic cells in this part are formed from trache and tracheids in both types have been created regular rows in radial direction. Druse crystals are clearly found in these (Figures 5, 6).

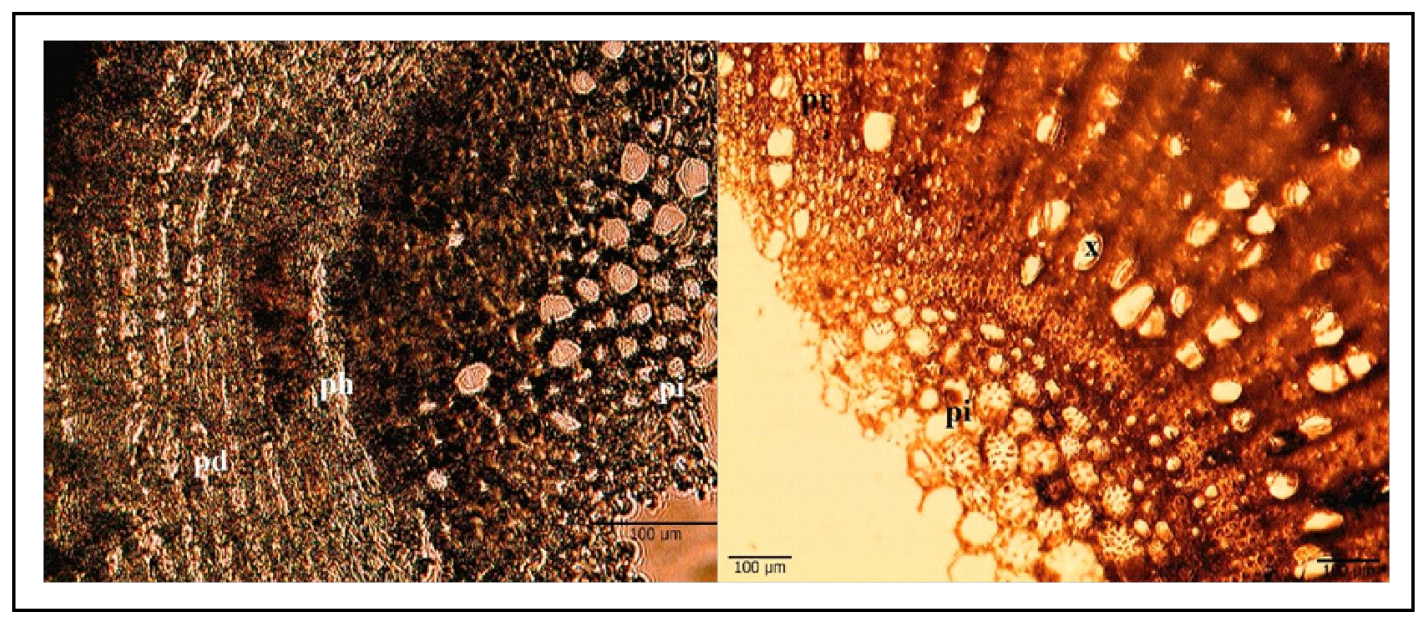

Figures 3-4: Stachys megalodonta subsp. mardinensis (ESSE 15295). Cross-section of root. pd-peridermis; ph-phloem; pi-pith; pr-pith ray; x-xylem.

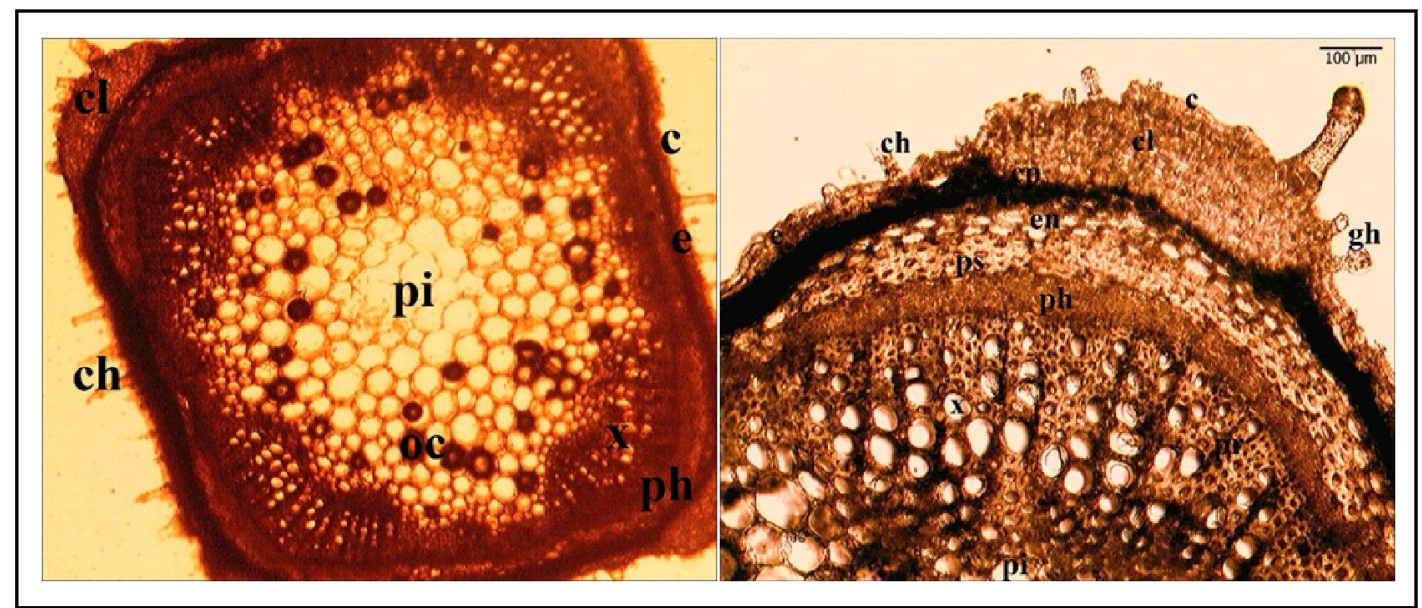

Figures 5-6: Stachys megalodonta subsp. mardinensis (ESSE 15295). Cross-section of herbaceous stem. A: diagrammatic, B: detail from, c: cuticle, ch: covering hair, e: epidermis, en:endodermis; cl: collenchyma, cp: cortex parenchyma, gh: glandular hair, oc: oil cells, $x$ : xylem, ps: pericyclic scleranchyma, ph: phloem, pr: pith ray, pi: pith. 


\subsubsection{Leaf}

In cross sections, epidermis is one layered and has roundish or rectangular cells with a thin cuticle; the cells of upper side are larger than lower side and the outer tangential walls are thickened, the anticlinal cell walls are sinuous in the lower side and are almost straight in the upper side. Covering and glandular hairs were observed on both upper and lower epidermis. Covering hairs: uniseriate, straight or recurved, 1-4 celled with smooth cuticle. Glandular hairs: head 1 stalk 1-2 celled and head 8 celled (Labiatae type); head 1 stalk 1-3 celled, head 2 stalk 1 celled. Stomata: the leaves amphistomatic, with diacytic superfacial or slightly raised above the epidermal level and more numerous on the lower side of the leaf. Mesophyll: bifacial, palisade tissue 1-2 layered, spongy parenchyma 3-4 layered (bifasiyal). Midrib: prominent arced in lower side. Below the upper and lower epidermis, there is a collenchyma tissue a few layered. Vascular bundles are collateral and phloem in the abaxial, xylem in the adaxial direction. Collenchymatic bundle caps present in the xylem and phloem poles (Figures 7-13). Stachys megalodonta subsp. mardinensis (ESSE 15295). Cross-section of herbaceous stem. Adiagrammatic, B detail from, c: cuticle, ch: covering hair, e: epidermis, en:endodermis, cl: collenchyma, cp: cortex parenchyma, gh: glandular hair, oc: oil cells; $x$ : xylem, ps: pericyclic scleranchyma, ph: phloem, pr: pith ray, pi: pith.

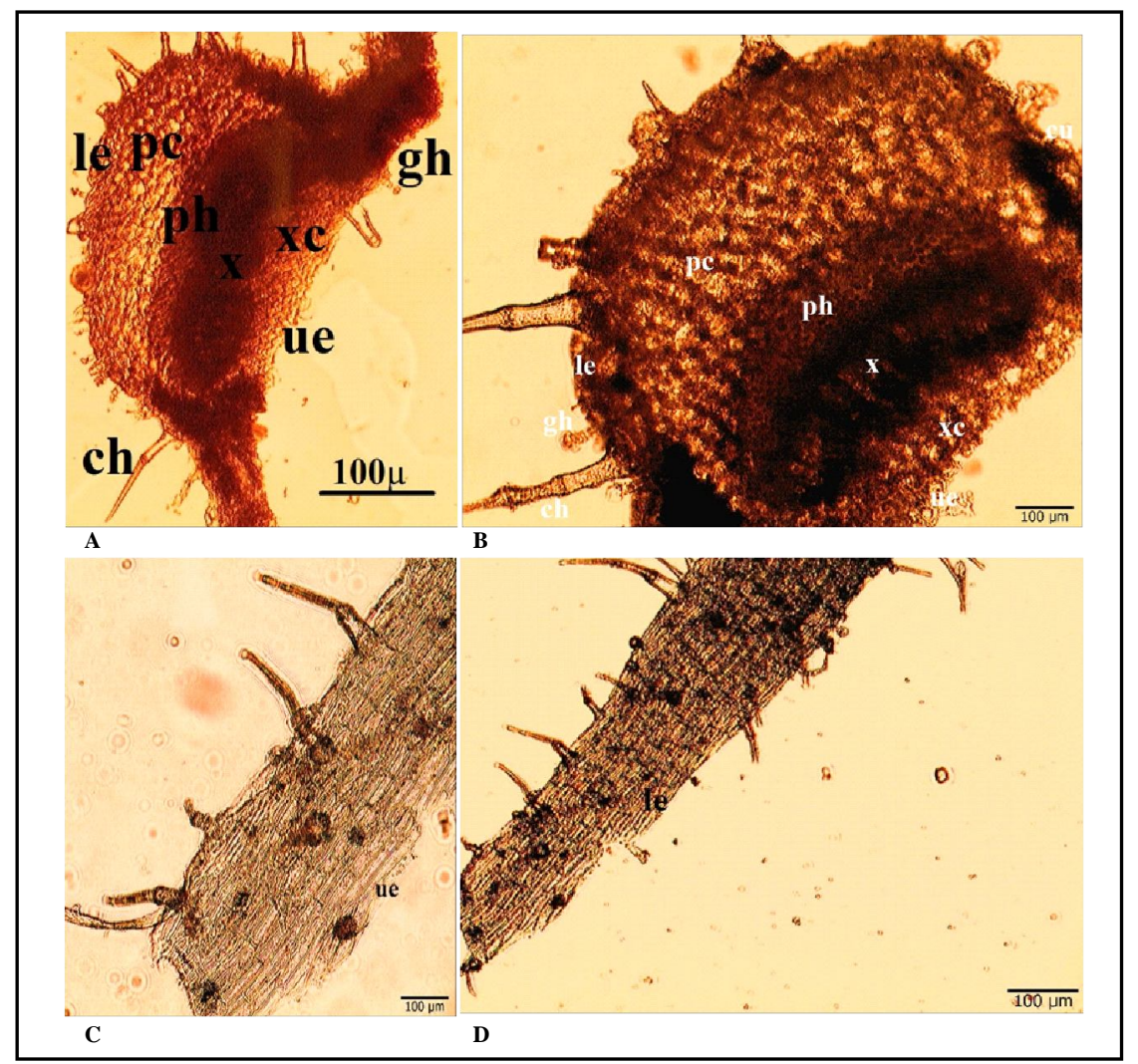

Figures 7-10: Stachys megalodonta subsp. mardinensis (ESSE 15295). Cross-section of the leaf: A diagram of the midrib, B detail from intervessel area; surface views of epidermis: C upper epidermis, D lower epidermis in LM, respectively, ue: upper epidermis, m: mesophyll, le: lower epidermis, cl: collenchyma, gh: glandular hair, ch: covering hair, p: parenchyma, pc: phloem collenchyma, ph: phloem, x: xylem, xc: xylem collenchyma, c: cuticle, pp: palisade parenchyma, s: stoma, sp: spongy parenchyma, vb: vascular bundle.

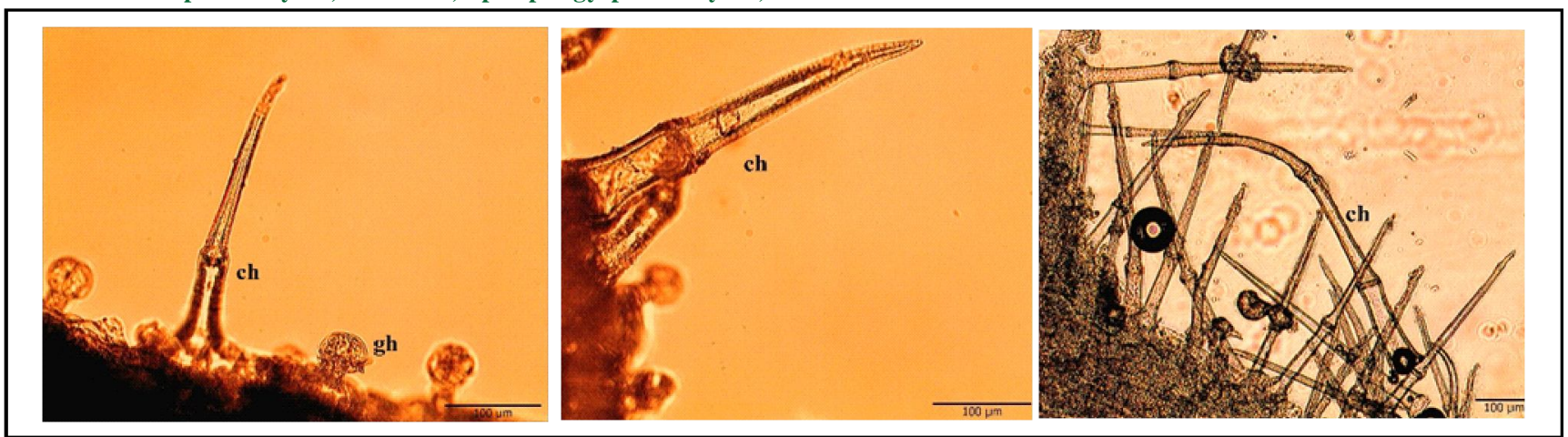

Figures 11-13: Covering and glandular hairs of Stachys megalodonta subsp. mardinensis. 
We hope that these results can be useful for chemotaxonomic classification of Stachys species. "Presented at the XII. International Symposium on the Actual Problems of Chemistry, Biology and Technology of Natural Compounds,7-8 September 2017, Tashkent.

\section{Conclusion}

Stachys species possess remarkable sedative, antispasmodic, stomachic and diuretic properties in tea preparations. In the present work, the aerial parts of Stachysme galodonta subsp. mardinensis were obtained essential oil. The main constituents were identified as $\alpha$-pinene, germacrene $\mathrm{D}, 1,8$-cineole and $\alpha$-caryophyllene. It's anatomical properties are described. To the best of our knowledge, this is the first report of the essential oil composition and anatomical properties.

\section{Conflict of interest}

The authors declare no conflicts of interest relevant to this article.

\section{References}

Akcicek, E., Dirmenci, T., Dundar, E. (2012). Taxonomical notes on Stachys sect. Eriostomum (Lamiaceae) in Turkey, Turk. J. Bot., 36:217234.

Akcicek, E. (2012). Stachys L. In: Güner, A., Aslan, S., Ekim, T., Vural, M. and Babaç M.T. (eds.). A Checklist of the Flora of Turkey Vascular Plants (Türkiye Bitkileri Listesi-Damarlý Bitkiler), Nezahat Gokyigit Botanik Bahcesi ve Flora Araptýrmalarý Dernegi Yayýný, Istanbul, 588-595.

Akcicek, E., Firat, M. and Guner, O. (2016). Stachys hakkariensis (Lamiaceae) A new species from eastern Anatolia (Turkey) belonging to Stachys sect. Olisia. Phytotaxa., 257:167-73.

Baser, K.H.C. and Kirimer, N. (2018). Essential oils of Anatolian Lamiaceae: An update, Nat. Volatiles and Essent. Oils, 5(4):1-28.

Baytop, T. (1999). Therapy with Medicinal Plants in Turkey (Past and Present), Publications of Istanbul University (2. edition), Istanbul, 193.

Bhattacharjee, R. (1974). Taxonomic studies in Stachys I: New species and infra-specific taxa from Turkey. Notes from the Royal Botanical Garden, Edinburgh, 33:275-292.

Bhattacharjee, R. (1980). Taxonomic studies in Stachys II: A new infrageneric classification of Stachys L. Notes from the Royal Botanical Garden, Edinburgh, 38:65-96.

Bhattacharjee, R. (1982). Stachys L. In: Davis P.H. (Ed.) Flora of Turkey and the East Aegean Islands, Edinburgh University Press, Edinburgh, 7:199-262.

Celep, F. and Dirmenci, T. (2017). Systematic and biogeographic overview of Lamiaceae in Turkey, Nat. Volatiles and Essent. Oils, 4(4):1427.

Davis, P.H., Mill, R.R. and Tan, K. (1988). Flora of Turkey and the East Aegean Islands, Edinburgh University Press. Edinburgh, 10:204 216
Dinc, M. and Dogu, S. (2015). Stachys gaziantepensis (Lamiaceae), a new species from South Anatolia, Turkey. Proceedings of the National Academy of Sciences, of India-Section B, Biological Sciences, pp: $1-5$.

Duman, H. (2000). StachysL. In: Guner A, Ozhatay N, Ekim T, Baper KHC. (Eds.), Flora of Turkey and the East Aegean Islands, Edinburgh University Press. Edinburgh, 11:204-206.

Duman, H., Kartal, M., Altun, L., Demirci B. and Baser, K.H.C. (2005). The essential oil of Stachys laetivirens Kotschy \& Boiss. ex Rech. f, endemic in Turkey, Flavour Fragr. J., 20:48-50.

Goger, F., Demirci, B., Ozek, G., Duman, H. and Baser, K.H.C. (2016). Essential oil composition of Stachys iberica Bieb. subsp. iberica from Turkey. Nat. Volatiles and Essent. Oils, 3(1):31-34.

Guner, O. and Akcicek, E. (2015). A new record for flora of Turkey: Stachys megalodonta Hausskn. and Bornm. ex P.H. Davis subsp. megalodonta (Lamiaceae), Baðbahce Bil. Derg., 2:27-32.

Goren, A. C., Goren, A.C., Piozzi, F., Akcicek, E., Kýlýc, T., Carýkcý, S., Mozioglu, E. and Setzer W.N. (2011). Essential oil composition of twenty-two Stachysspecies (mountain tea) and their biological activities. Phytochem. Lett., 4:448-453.

Iscan, G., Demirci, B., Demirci, F., Goger, F., Kirimer, N., Kose, Y. B. and Baser, K. H.C. (2012). Antimicrobial and antioxidant activities of Stachys lavandulifolia subsp. lavandulifolia essential oil and its infusion, Nat. Prod. Commun., 7(9):1241-1244.

Karaboduk, K., Karabacak, O., Yiyit Dogan, S., Karaboduk, H., Gunduzer, E. and Tekinay, T. (2014). Comparison of antimicrobial, antioxidant capacities and HPLC analysis of three stachys species in Turkey, J. Environ. Prot. Ecol., Special Issue, 15(3A):1293-1302.

Kaya, A., Demirci, B. and Baser, K.H.C. (2001). The Composition of the Essential Oil of Stachys iberica subsp. stenostachya Growing in Turkey, Chem. Nat. Compd., 37(4):326-328.

Kaya, A., Demirci, B., Dogu, S., and Dinc, M. (2017). Composition of the essential oil of Stachys sericantha, S. gaziantepensis, and $S$. mardinensis (Lamiaceae) from Turkey, Int. J. Food Prop., 20 (11):2639-2644.

Kucuk, S., Cetintas, E. and Kurkcuoglu, M., (2019). Volatile compounds of the Lavandula angustifolia Mill. (Lamiaceae) species cultured in Turkey., Reviews 5(3):1303-1308.

Renda, G., Bektas, N.Y., Korkmaz, B., Celik, G., Sevgi, S. and Yaylý, N. (2017). Volatile constituents of three Stachys L. species from Turkey. Marmara Pharmaceutical Journal, 21(2):278-285.

Salmaki, Y., Zarre, S., Govaerts, R. and Brauchler, C. (2012). A taxonomic revision of the genus Stachys (Lamiaceae: Lamioideae) in Iran, Botanical Journal of the Linnean Society, 170:573-617.

Serbetci, T., Demirci, B., Bozkurt Guzel, C., Kultur, S., Erguven, M. and Baser, K.H.C. (2010). Essential oil composition, antimicrobial and cytotoxic activities of two endemic Stachys cretica subspecies (Lamiaceae) from Turkey. Nat. Prod. Commun., 5(9):1369-1374. 